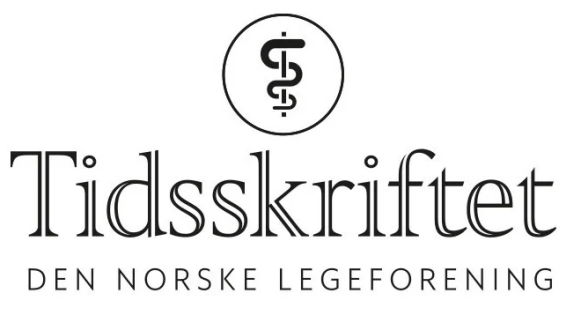

\title{
På sporet av en svunnen tid
}

INTERVJU

ANNE KATHRINE SEBJØRNSEN

annekaths@hotmail.com

- Er sykehusdriften kommet dit vi ville, eller har vi sporet av? Nils O. Lid mener han har opplevd gullalderen der alt vokste og forbedret seg, men den delvis pensjonerte overlegen kjenner nå på en tristesse og en oppgitthet over utviklingen. 


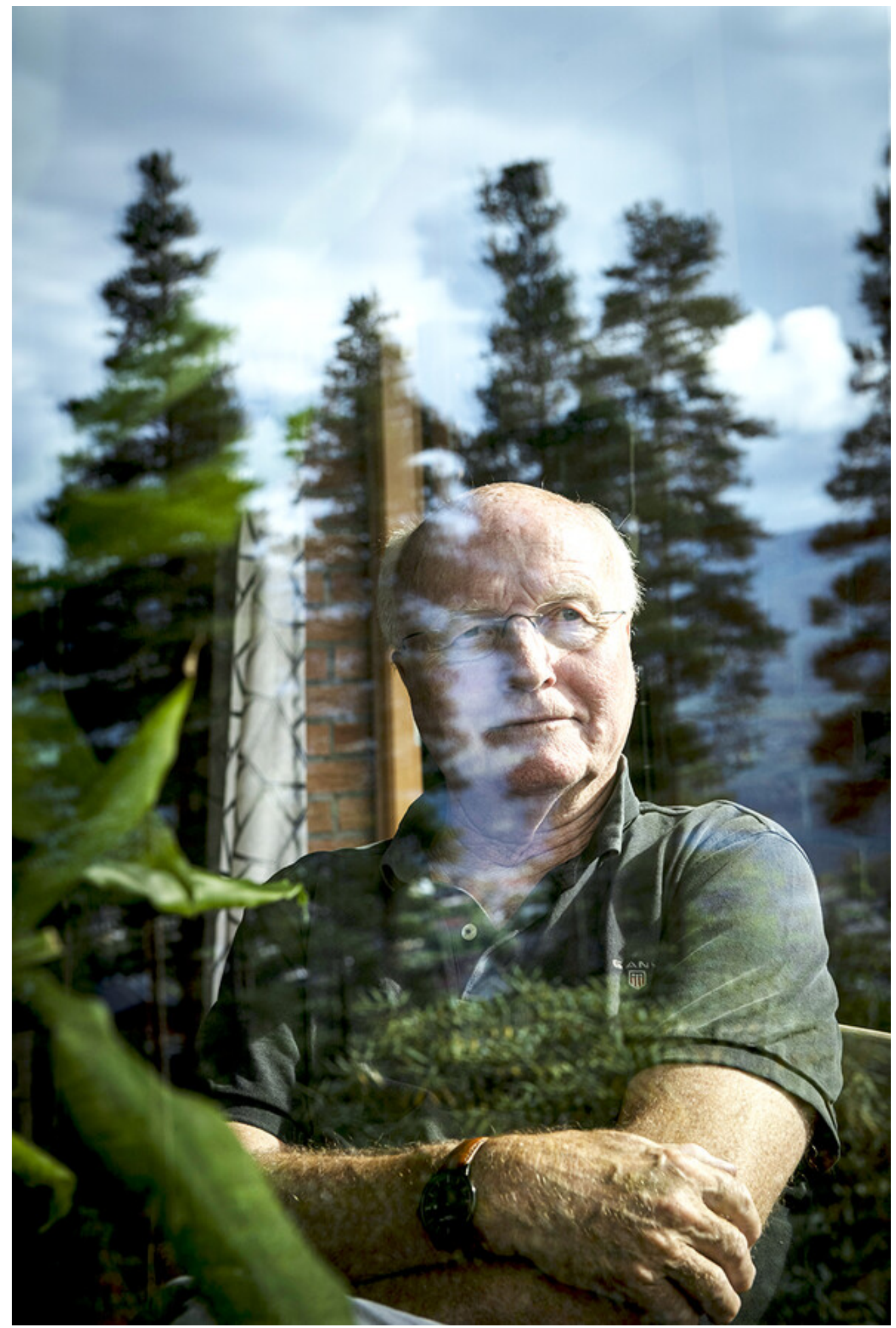

Foto: Hilde Mesics Kleven

Han tar imot i inngangen til Notodden sykehus ett minutt før tiden og viser vei inn på et bakrom på medisinsk poliklinikk, der interiøret ser ut til å ha stått ganske urørt siden han begynte her som overlege en i julidag i 1984. Han har ledet avdelingen støtt i vekstfaser og under trussel om nedleggelse. Nå er han delvis pensjonist, men trives for godt med indremedisinen til å gi seg helt.

- Jeg har opplevd en gullalder der alt vokste og utviklet seg. Det har vært en eventyrlig reise med faglige fremskritt og sykehuset som en fantastisk bedrift. Teknologien ble bedre og lettere tilgjengelig. Vi hadde stabil drift og utdannet egne spesialister, forteller han entusiastisk. 
«På mange måter har vi beveget oss fra å drive legekunst til å bli

forbrukerkonsulenter for medisinsk velvcere»

Han trekker frem historien om det lokale engasjementet, kronerullingen og bystyret som bevilget en million kroner for å få den første CT-maskinen til sykehuset i slutten av 1980årene.

- Min kollega Borgar Flaaten overbeviste folk om behovet, og lokalmiljøet engasjerte seg, forteller han og lyser opp.

Han lener seg tilbake, kaster et blikk ut vinduet med utsyn mot inngangen til akuttmottaket der han har tatt imot dårlige pasienter fra Notodden og omegn i en årrekke. Indremedisineren har mye på hjertet. Som deltidspensjonist er det blitt mer tid til å reflektere. 


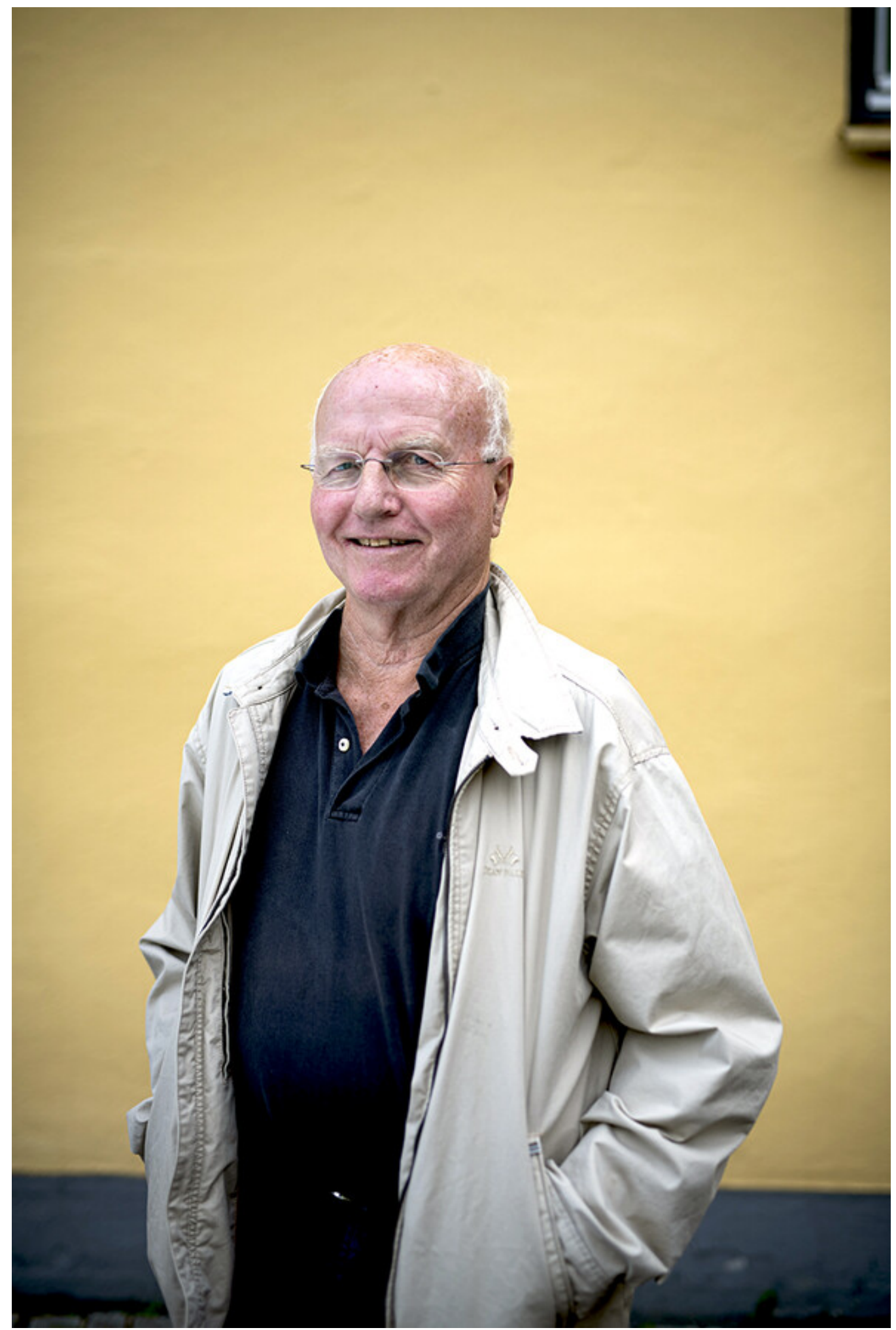

Foto: Hilde Mesics Kleven

- Til tross for at vi aldri har vært flere leger, finnes det få arenaer der vi drøfter de overordnede strukturene. Jeg kjenner på en tristesse og en oppgitthet over utviklingen. På mange måter har vi beveget oss fra å drive legekunst til å bli forbrukerkonsulenter for medisinsk velvære. Jeg tror mange sykehusleger har en opplevelse av at de «bare jobber her», at de ikke har en reell påvirkningsmulighet - dessverre.

Kolleger forteller at han er opptatt av etikk, og at han ofte utfordrer dem på etiske betraktninger.

- Er medisinsk etikk blitt et fikenblad, eller er det et normdannende virkemiddel? Det er krav om etiske råd på sykehus, men hvor ofte har vi egentlig en lang diskusjon der vi kvalitetssikrer våre beslutninger ut ifra et etisk kompass? 
Bordet er sirlig dekket, han har med kaffe på kanne, og kona Anne Kathrine har sendt med hjemmebakt eplekake med krem. Han trekker pusten.

- Også er det DRG-systemets forbannelse. Pasienten beskrives som ordremasse, og pasientbehandling er et middel til å nå økonomiske mål. Protesekirurgi ble børsvinneren, medisinsk vedlikeholdsbehandling ble det ikke, sier han og hever et øyebryn mens han tar en bit.

- God, ikke sant? Han smiler.

- Det er favorittkaken min.

\section{Solidaritet i morsmelken}

- Hvorfor skal du intervjue meg, egentlig? Det er da ikke noe å skrive om meg?

Han virker oppriktig undrende. Av kolleger beskrives han imidlertid som en av bautaene som ivaretar høyt faglig nivå og stabilitet på et lokalsykehus som har vært under press i mange år. Lokale fastleger forteller at han har en ektefølt entusiasme for førstelinjen og at han gjerne drar ut fra sykehuset for å møte fastlegene der de er. En fastlege i distriktet beskriver det som en uvurderlig støtte «å ha en Nils på laget».

Som leder beskrives han som en som får ansatte til å føle seg viktige, en som samler profesjoner og skaper et godt arbeidsmiljø, gjerne ved bruk av humor og morsomme historier man kan lære av.

Engasjementet for pasientene strekker seg ofte langt utover det medisinskfaglige.

Det sosiale engasjementet har vært der fra barnsben av.

- Moren min drømte om å bli bibliotekar, men det lot seg ikke gjøre, og hun ble hjemmeværende. Vi søsknene vokste opp i stor nøkternhet, og foreldrene våre lærte oss tidlig om solidaritet. De var opptatt av å stå opp for urett og å ta vare på andre, forteller han.

\section{Klassereisen}

Nils Opheim Lid ble født i Ulefoss i Telemark, som tredjemann i en søskenflokk på fire. Selv ble han oppkalt etter morfaren fra Voss, som var fylkesagronom og reiste rundt og lærte bønder hvordan de kunne finne nyttevekster i naturen.

«Det var herdende å vcere litt radikal på Bygdøy»

Faren arbeidet som journalist i Telemark Arbeiderblad (TA) frem til krigen brøt ut. Avisen ble stengt ned da redaksjonen ikke underla seg tyskerne. For å livnære familien ble faren skogsarbeider under Cappelen på Ulefoss og i Lunde. Faren søkte seg inn på jusstudiet i Oslo, og senere skulle han bli professor i landbruksrettsvitenskap.

I maidagene 1945 var faren med på å overta NRK, og han ble sekretær for kringkastingssjefen. Den nøkterne familien Opheim Lid flyttet dermed inn en statstjenestebolig på Bygdøy med seks mål tomt som blant annet hadde blitt brukt av Vidkun Quisling som feriebolig.

- Jeg er et såkalt «fredsbarn». I gutteklassen på Bygdøy folkeskole var vi 32 på det meste. Aldri hadde det vært et større kull, forteller han.

\section{En radikaler på Bygdøy}


Den unge Nils skilte seg ut på flere vis på Bygdøy. Han var pasifist og aktiv i bevegelsen Nei til atomvåpen.

- Jeg hadde en medfødt ryggfeil, og dermed ble jeg heldigvis innkalt til Sivilforsvaret. Jeg har også en øyeskade, forteller han.

Da han var fire år skjøt han seg selv i øyet under lek med pil og bue hjemme i hagen. Øyeskaden førte til at han fikk grå stær på det ene øyet.

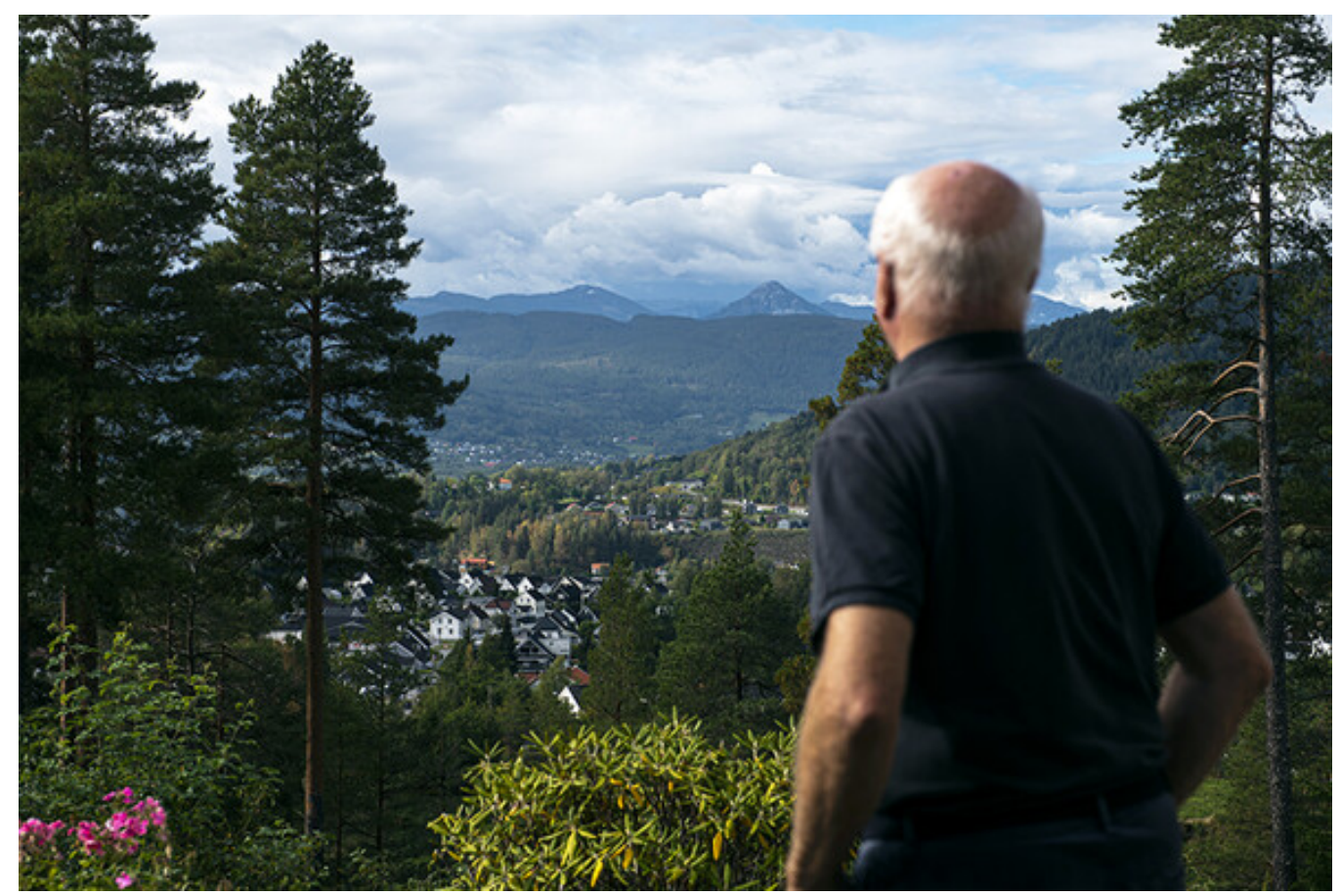

Foto: Hilde Mesics Kleven

- Foreldrene mine slet med skyldfølelse for at de ikke hadde tatt meg til lege. De lurte alltid på om de kunne ha gjort noe for å forebygge at jeg fikk grå stær, forteller han.

Øyeskaden har ikke lagt noen store begrensninger på hverken privatliv eller karriere, men kirurgi fant han snart ut at det var greiest å holde seg unna.

\section{«Problemet er at jeg har veldig vanskelig for å kvitte meg med ting»}

- Avstandsbedømmelse er veldig vanskelig for meg. Når vi skulle lukke operasjonssåret, måtte jeg alltid legge hodet på skakke for å forsøke å få en oppfatning av hva som var riktig lengde på tråden. Det var ikke derfor jeg ga opp kirurgien, men det var helt klart en praktisk utfordring.

Da yrkesutdanning ble et tema i gymnastiden, fikk han støtte fra foreldre og søsken om å studere medisin, selv om det innebar å reise utenlands.

- Karakterene mine var middels, og jeg var veldig glad for å få studieplass i Dublin. Det var høye semesteravgifter, men med årene ble Lånekassen mer raus. Jeg hadde seks gode år i Irland, og det var vemodig å forlate landet. Jeg fikk med meg veldig mye mer enn «bare» legeutdannelsen. Dessuten rakk jeg å stemme nei til EEC i både Irland og Norge, utbryter han fornøyd.

- Ingen valgkrets i Norge hadde en høyere andel som stemte ja, så vi som stemte nei, kjente til hverandre. Det var herdende å være litt radikal på Bygdøy, sier han med et lite smil om munnen.

\section{Epidemien som endret ham}


Turnustjenesten ble gjennomført ved Bodø sykehus, før turen gikk til distriktstjeneste i Bø i Vesterålen. Han glemmer ikke de sterke kvinnene som ordnet opp uansett hva som skjedde i kommunen.

- Det var en helsesøster fra menighetssykepleierskolen som tok seg av det meste i kommunen som ikke ble håndtert av lege eller tannlege. Hun stelte døde, behandlet kroniske leggsår osv. Jeg tror nærmest arbeidet var et kall for henne, forteller han engasjert.

\section{Nils Opheim Lid}

\section{Født 2.3.1946 i Ulefoss i Telemark}

Medisinsk embedseksamen, Royal College of Surgeons in Ireland 1972

Spesialist i indremedisin 1982

Spesialist i kardiologi 1983

Overlege ved Medisinsk avdeling, Notodden sykehus 1984

Sjeflege ved Notodden sykehus 1990-97

Avdelingsoverlege ved Medisinsk avdeling, Notodden sykehus 1996-2002

Tillitsvalgt i Overlegeforeningen i to perioder

Pensjonist og deltidsarbeidende overlege på Medisinsk avdeling, Notodden sykehus

Sentralborddamene var også uunnværlig hjelp når legene måtte rykke ut til syke. Langs veien gikk det saueflokker, det var lite gatelys og mørkt midtvinters.

- Dette var en tid da vi opererte med sveivetelefon og sentralbord. Damene på sentralbordet fungerte som datidens GPS. De grep inn hvis vi kjørte feil, og det gjorde vi jo støtt, minnes han.

Sykehuslivet fortsatte som assistentlege og senere konstituert reservelege på Gravdal sykehus i Lofoten. På den tiden brøt det ut en meningokokkepidemi som rammet både Nordland, Troms og Finnmark, der over 30 mennesker døde av meningokokkmeningitt. Det satte varige spor hos den unge sykehuslegen.

- Det var mange barn som døde. Spesielt gikk det inn på meg at to brødre døde i løpet av en uke. Vi var ganske alene som sykehusleger. Vi hadde ikke barneavdeling i Bodø og måtte bare gjøre så godt vi kunne. Det var universitetssykehus i Tromsø, men det var ikke aktuelt med overflytning dit.

- Hvordan påvirket det deg?

- Jeg bestemte meg der og da for at jeg ikke ville bli pediater. Det var en veldig skremmende opplevelse å se hvor raskt friske barn kunne bli syke og dø, forteller han. Bekymringen hadde fått feste. Ulike scenarioer for sykdom som kunne ramme barn, spilte seg ut $\mathrm{i}$ hodet. Pediater ble han ikke, men da Hallvard og Guro ble født med et par års mellomrom ble han likevel «huslege» for egne barn.

- På den tiden var vi nok alle leger for egen familie, det ble bare sånn. Helt heldig var det nok ikke, sier han, og minnes spesielt en gang sønnen fikk langvarig feber.

- Vi skjønte ikke hva feberen kom av eller hvorfor det ikke gikk over. Jeg ble så bekymret at jeg dro ham med til fire ulike spesialister på samme dag. Dagen etter var feberen naturligvis borte, sier han og ler.

\section{Rotfeste}


- Jeg ble fort klar over at det var sykehuslege jeg ville være, og spesialiserte meg i indremedisin. At det også ble kardiologi, er egentlig tilfeldig. Jeg fikk jobb på gamle 8. avdeling på Ullevål sykehus som assistentlege. Der hadde jeg gode, formende år, minnes han.

Det var imidlertid vanskelig å få overlegestilling. I Oslo var det stillingsstopp, og det unge paret var opptatt av at barna skulle få vokse opp og føle tilhørighet til ett sted. Notodden hadde han reist gjennom fra barnsben av, på vei til Morgedal og Grønlihei, hvor foreldrene hadde hytte.

- Min kone, som er prestedatter, hadde sterke synspunkter på den saken. Hun hadde selv en rotløs oppvekst. Da Tidsskriftet annonserte ledig stilling som assisterende overlege på Notodden, var det en selvfølge at jeg søkte. Det var ikke så mange andre søkere, så jeg fikk tilbudet, sier han beskjedent.

Kulturlivet i Oslo trekker likevel.

- Jeg vokste opp i et liberalt og kulturelt hjem med lett tilgang til teater og opera. Nå er vi faste abonnenter i operaen og ser mange teaterstykker i løpet av året. Veiene mellom Notodden og Oslo har blitt veldig gode, og kjøreturen hjem etter en forestilling går unna på 90 minutter, sier han ivrig.

- Jeg er ikke blitt patriot, altså, men har en sterk tilhørighet til byen, understreker han.

\section{Samleren}

Når man trer over dørstokken til overlegens hjemmekontor, vil man fort kunne snuble i en stabel av medisinske artikler og tidsskrifter om man ikke ser seg for. Kontoret hans på sykehuset er dessuten såpass rotete at turnuslegene har begynt å inkludere det i sitt faste rebusløp. «Hvem sitt kontor er dette?» lyder spørsmålet. Og alle vet svaret.

- Det er rett og slett litt kaotisk, må jeg innrømme. Jeg er en uforbederlig rotekopp.

Problemet er at jeg har veldig vanskelig for å kvitte meg med ting. Spesielt er det umulig å kaste Tidsskrift for Den norske legeforening. Jeg har min egen variant av «hurtigarkivering», og har laget en haug med artikler jeg planlegger å lese, sier han og sukker.

Utfordringen ligger altså ikke i at han ikke leser artiklene, for det gjør han før eller siden, men at det er så mye han blir engasjert i samtidig. Ukens høydepunkt er fagbokanmeldelser og litteraturanmeldelsene i Klassekampen.

- Oftest leser jeg 5-6 bøker parallelt. Jeg er lett å engasjere og lar meg stadig rive med i noe nytt og spennende. Jeg har forsøkt å begrense meg til én ting av gangen, men så klarer jeg ikke å stå imot fristelsen til å starte på noe annet, forteller han entusiastisk.

Den digitale tidsalderen har han imidlertid gjort sitt beste for å stå imot.

- I bilen hører jeg på lydbok, så litt moderne er jeg jo. Ellers har jeg forsøkt å unngå å bli særlig digital, til tross for at jeg var den første og eneste datatillitsvalgte på sykehuset i slutten av 1980-åra. Sykehuset skulle ta i bruk edb-systemer, og ingen andre ville, sier han.

- Det er en liten protest?

- Lenge insisterte jeg på å møte opp i banken fysisk for å betale fakturaene mine. Det gikk jo litt sport i det, og jeg tenkte at det der nettbankopplegget gidder jeg faen ikke. Til slutt ringte de fra lokalfilialen og insisterte på å gi meg privat opplæring i bruk av nettbank. Da ga jeg meg. Uansett mener jeg at det ikke er så farlig om jeg er litt hjelpeløs på akkurat dette. Alle andre kan det jo. Vi har dessuten en sønn som er dataingeniør. Han har tilgang til vår familie-pc og kan både veilede og overta når vi har satt oss fast.

Nils O. Lid samler sammen koppene og asjettene. Kveldssolen skinner inn gjennom vinduet. På medisinsk avdeling er det fortsatt noe å gjøre. 
Publisert: 11. oktober 2021. Tidsskr Nor Legeforen. DOI: 10.4045/tidsskr.21.0598

(C) Tidsskrift for Den norske legeforening 2023. Lastet ned fra tidsskriftet.no 26. april 2023. 